\title{
Mesenchymal stem cells from amnion and amniotic fluid in the bovine
}

\author{
B Corradetti $^{1,2}$, A Meucci $^{2}$, D Bizzaro $^{1}$, F Cremonesi $^{2,3}$ and A Lange Consiglio ${ }^{2}$ \\ ${ }^{1}$ Department of Life and Environmental Sciences, Università Politecnica delle Marche, Ancona, Italy, ${ }^{2}$ Reproduction \\ Unit, Large Animal Hospital, Università degli Studi di Milano, Via dell'Università 6, 26900 Lodi, Italy and \\ ${ }^{3}$ Department of Veterinary Science for Animal Health, Production and Food Safety, Università degli Studi di Milano, \\ Milano, Italy
}

Correspondence should be addressed to F Cremonesi at Reproduction Unit, Large Animal Hospital, Università degli Studi di Milano; Email: fausto.cremonesi@unimi.it

\begin{abstract}
Amnion and amniotic fluid (AF) are noncontroversial and inexhaustible sources of mesenchymal stem cells (MSCs) that can be harvested noninvasively at low cost. As in humans, also in veterinary field, presumptive stem cells derived from these tissues reveal as promising candidates for disease treatment, specifically for their plasticity, their reduced immunogenicity, and high anti-inflammatory potential. The aim of this work is to obtain and characterize, for the first time in bovine species, presumptive MSCs from the epithelial portion of the amnion (AECs) and from the AF (AF-MSCs) to be used for clinical applications. AECs display a polygonal morphology, whereas AF-MSCs exhibit a fibroblastic-like morphology only starting from the second passage, being heterogeneous during the primary culture. For both lines, the proliferative ability has been found constant over the ten passages studied and AECs show a statistically lower $(P<0.05)$ doubling time with respect to AF-MSCs. AECs express MSC-specific markers (ITGB1 (CD29), CD44, ALCAM (CD166), ENG (CD105), and NT5E (CD73)) from P1 to P3; in AF-MSCs, only ITGB1, CD44, and ALCAM mRNAs are detected; NT5E is expressed from P2 and ENG has not been found at any passage. AF-MSCs and AECs are positive for the pluripotent markers (POU5F1 (OCT4) and MYC (C-Myc)) and lack of the hematopoietic markers. When appropriately induced, both cell lines are capable of differentiating into ectodermal and mesodermal lineages. This study contributes to reinforce the emerging importance of these cells as ideal tools in veterinary medicine. A deeper evaluation of the immunological properties needs to be performed in order to better understand their role in cellular therapy. Reproduction (2013) 145 391-400
\end{abstract}

\section{Introduction}

As in humans, also in veterinary medicine, mesenchymal stem cells (MSCs) have been harvested successfully from a wide range of tissues (Smith et al. 2003, Kern et al. 2006, Koerner et al. 2006, Arnhold et al. 2007, Giovannini et al. 2008, Vidal et al. 2008). The most characterized sources of MSCs are bone marrow (Fortier et al. 1998, Ringe et al. 2002, Mitchell et al. 2003, Smith et al. 2003, Kern et al. 2006, Vidal et al. 2006, Arnhold et al. 2007, Vidal et al. 2008) and the adipose tissue (Kern et al. 2006, Vidal et al. 2008); however, the procedures employed to isolate these tissues are still invasive and cells are usually obtained with low efficiency. Furthermore, their differentiative and proliferative potential has been reported to decrease with the age of the donor (Pittenger et al. 1999). The possibility to collect a large amount of cells, in an inexpensive and noninvasive way, and without being risky for the donor is of a great concern for regenerative medicine and cellular therapy, especially if there is the chance to expand the cells in vitro and to cryogenically bank (Carlin et al. 2006, Cremonesi et al. 2008).

As such, gestational tissues including umbilical cord blood (Kern et al. 2006, Koch et al. 2007, Guest 2008, Reed \& Johnson 2008, Bartholomew et al. 2009, Schuh et al. 2009, Seo et al. 2009, Raoufi et al. 2011), umbilical cord tissues (Mitchell et al. 2003, Carlin et al. 2006, Hoynowski et al. 2007, Cremonesi et al. 2008, Passeri et al. 2009, Corradetti et al. 2011, Lovati et al. 2011, lacono et al. 2012a), amniotic tissues (Filioli Uranio et al. 2011, lacono et al. 2012a, 2012b, Lange-Consiglio et al. 2012), and amniotic fluid (AF) (Chen et al. 2011, Dev et al. 2011, Lovati et al. 2011, lacono et al. 2012a) have been recently suggested, also in veterinary medicine, as appealing candidates for the derivation of MSCs to use in cell biotechnology. The human lesson teaches that presumptive adult stem cells derived from gestational tissues retain highest proliferation capacity, longest telomere length, broadest 
differentiation, and extensive proliferative potential when compared with cells obtained from adult tissues (Kogler et al. 2004, Kern et al. 2006). In particular, MSCs obtained from human amnion have been shown to retain immunomodulatory properties as well as to strongly inhibit T lymphocyte proliferation (Magatti et al. 2008) and to survive when transplanted in immunocompetent animals without inducing any tumorigenic effect in vivo (Avila et al. 2001, Kubo et al. 2001, Sankar \& Muthusamy 2003, Yuge et al. 2004). As amnion-derived progenitor cells, MSCs from AF (AF-MSCs) are thought to be in an intermediate stage between embryonic stem cells and lineage-restricted adult stem cells (In 't Anker et al. 2004, Delo et al. 2006, De Coppi et al. 2007, Sessarego et al. 2008, Gucciardo et al. 2009), originating from several fetal tissues, including skin, digestive, respiratory, and urinary systems (Prusa \& Hengstschlager 2002, You et al. 2009, Da Sacco et al. 2010). AF-MSCs are known to play a role in preventing rejection of the fetus and are thought to have low immunogenicity (Wang et al. 2006). In addition to this, no karyotypic abnormalities or transformation potential in vitro have been still associated with amnion- or AF-derived cells (Sessarego et al. 2008).

In veterinary field, the amniotic membrane has been employed for ocular surface reconstruction in dog (Arcelli et al. 2009) and horse (Ollivier et al. 2006, Plummer et al. 2009) due to its ability to promote re-epithelialization, to reduce fibrosis (Solomon et al. 2005), and to modulate angiogenesis (Dua et al. 2004).

Even if amnion has been widely used in clinical therapies, we have been the first to isolate and characterize presumptive MSCs derived from the equine amniotic membranes (both epithelial and mesenchymal portions) and to demonstrate their application in clinical regenerative medicine, in particular for the treatment of spontaneous tendon injuries in horses (Lange-Consiglio et al. 2012). However, for other species, the potential of these cells or those obtained from the AF to be used in cellular therapy needs to be fully determined, and further in vitro and in vivo investigations are needed.

Despite the importance of bovine species as model for in vivo studies, little is known about bovine MSCs. So far, they have been derived from umbilical cord blood (Raoufi et al. 2011) and bone marrow (Bosnakovski et al. 2005, 2006) and attempts to isolate cells from the amniotic membrane or from the AF have not been reported in the literature yet.

The aim of the present work is to isolate presumptive MSCs from the epithelial portion (Miki et al. 2005, 2007a) of the amnion (AECs) and from the AF and to characterize them in terms of morphology, specific mesenchymal or pluripotent markers, and proliferative and differentiative potential.

\section{Results}

\section{Amnion collection and isolation of amniotic epithelial cells}

Cells were selected purely on their ability to adhere to plastic. Isolated cells readily attached to plastic culture dishes. AECs displayed typical polygonal epithelial morphology, whereas AF-MSCs observed during primary culture consisted of two types of cells: one was similar to fibroblasts and others were flat and circular, resembling epithelial cells. Starting from the second passage, the AF-MSCs became homogeneous exhibiting fibroblastlike morphology. Representative images are shown in Fig. 1.

\section{Proliferation assays}

For both cell lines, AECs and AF-MSCs, the proliferative ability has been found constant over the ten passages studied with an average of $1.34 \pm 0.30$ and 2.06 \pm 0.37 days for AECs and AF-MSCs respectively. Differences between AECs and AF-MSCs doubling times (expressed as days) were observed at $\mathrm{P} 6$, when AECs showed a statistically lower $(P<0.05)$ doubling time $(1.08 \pm 0.46)$ with respect to AF-MSCs (2.69 \pm 0.32 . Differences observed between AECs and AF-MSCs doubling times at other passages were not significant (Fig. 2).

The number of cell colonies formed was counted at P0 after seeding cells at different density $/ \mathrm{cm}^{2}$ as previously reported (Lange-Consiglio et al. 2012). Both AECs and AF-MSCs demonstrated a statistically significant increase in colony-forming unit (CFU) frequency with increasing cell-seeding densities. For each density of seeding (with the exception of the 100 cells $\left./ \mathrm{cm}^{2}\right)$, AECs showed a significantly higher CFU $(P<0.05)$ in comparison to AF-MSCs (Table 1).

\section{RNA extraction and RT-PCR analysis}

As shown by RT-PCR (Fig. 3), amnion-derived cells (AECs) expressed MSC-specific markers (ITGB1 (CD29), CD44, ALCAM (CD166), ENG (CD105), and NT5E $(C D 73)$ ) over the three passages studied (from P1 to $\mathrm{P} 3$ ). In cells isolated from AF, only ITGB1, CD44, and ALCAM mRNAs were detected from P1 to P3. Expression of NT5E was only observed from P2, whereas ENG was not detected at any stage. Cells from amnion and $\mathrm{AF}$ were positive for the pluripotency-associated markers studied (POU5F1 (OCT4) and MYC (C-Myc)) and lacked of CD34,CD14, and PTPRC (CD45) over the passages studied. Major histocompatibility complex, class I (MHC-I) expression was demonstrated in each cell population, while $M H C-I l$ was expressed nor in AECs or in AF-MSCs. 


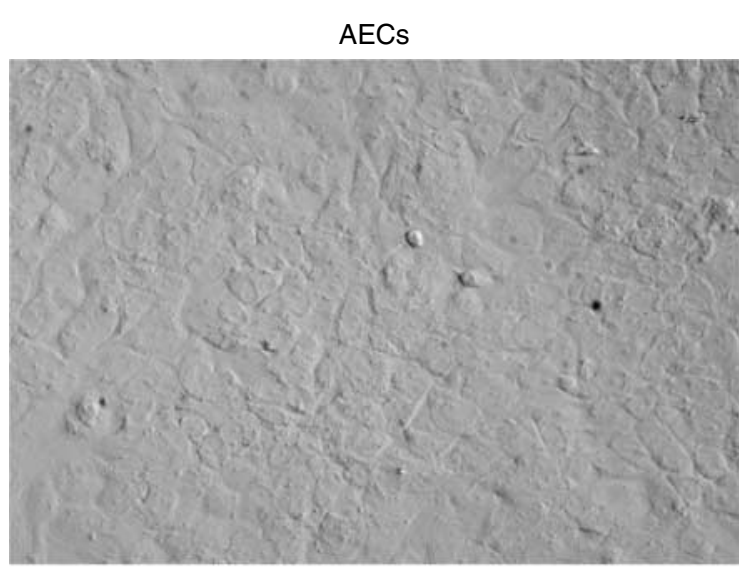

AF-MSCs

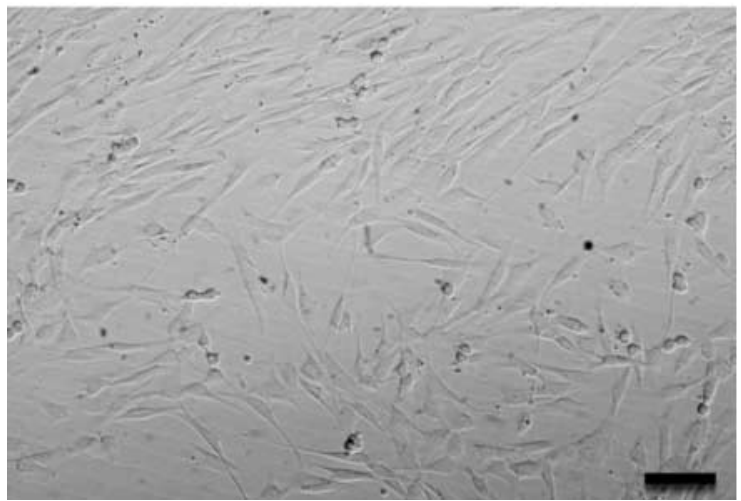

Figure 1 Cell morphology. Monolayer of adherent polygonal epithelial AECs and spindle-shaped fibroblastic-like AF-MSCs. Magnification, $20 \times$; scale bar, $20 \mu \mathrm{m}$.

\section{Multipotent differentiation}

Molecular analysis of bovine adult tissues (fat, cartilage, and spinal cord) showed the expression of the specific genes evaluated (Fig. 4). After 3 weeks of culture in adipogenic medium, both amnion- and AF-derived cells developed lipid deposits as demonstrated by the Oil red $\mathrm{O}$ staining. Cells maintained in regular control medium did not stain positively (Fig. 4A). For AECs, differentiation was confirmed by peroxisome proliferator-activated receptor- $\gamma(P P A R G)$, adipocyte fatty acid-binding protein (FABP4), and leptin (LEP) expression, whereas AF-MSCs only expressed FABP4 and $L E P$ (Fig. 4B).

Chondrogenic differentiation has been identified by Alcian blue staining as an evident deposition of glycosaminoglycans in the matrix (Fig. 4A). In both cell types, the early marker for chondrogenesis SOX9 has been detected with the consequent expression of aggrecan $(A C A N)$. mRNAs for COL2A1 were only detected, at a basal level, in AF-MSCs (Fig. 4B).

Three days were enough to induce neurogenic differentiation. Changes in cell morphology were evident as cells (both AECs and AF-MSCs) adopted a typical morphology of neural cells, with dendrite-like processes (Fig. 4A). Both cell populations expressed nestin (NES), but in AECs, glial fibrillary acidic protein (GFAP) mRNAs were also detected (Fig. 4B).

\section{Discussion}

Extra-gestational tissues have been widely suggested to be the ideal sources of MSCs due to their accessibility, being usually discarded at birth (Parolini et al. 2008, 2009). Although amnion is a thin membrane composed of two different portions, the mesenchymal and the epithelial one, we decided to focus our attention on the derivation of progenitor cells from the epithelial area of placenta. In 2005, Miki et al. (2005) reported that cells obtained from the fetal side of placenta might retain a multipotent phenotype even after the differentiation from the epiblast. The aim of this study was to characterize, for the first time in bovine species, cells obtained from the amniotic epithelial membrane and the AF and to evaluate these tissues as potential candidates for the isolation of progenitor cells to employ in cellular therapies.

Our in vitro differentiation studies support the findings already reported in humans (In 't Anker et al. 2004, De Coppi et al. 2007) and in equine species (Lange-Consiglio et al. 2012): cells isolated from the amniotic epithelial portion, as well as those obtained from the $A F$, show high plasticity, being able to differentiate into multiple germ layers (mesoderm and ectoderm). In particular, according to data obtained from human amniotic epithelial cells (Miki et al. 2005, 2007a), we prove the ability of bovine amnion-derived cells to undergo astrocyte differentiation, as demonstrated by GFAP expression following neurogenic induction. On the contrary, in cells derived from AF, only the presence of NES, a marker expressed in neuronal precursor stem cells, has been detected, confirming the neurogenic induction occurred as previously observed in pig (Zheng et al. 2010). Both cell lines converted into a typical neuron-like morphology when appropriately induced.

When stimulated to differentiate toward the adipogenic lineage, both cell lines stained positively for Oil red $O$ staining and expressed genes involved in lipid biosynthesis and storage. In induced AEC mRNAs for

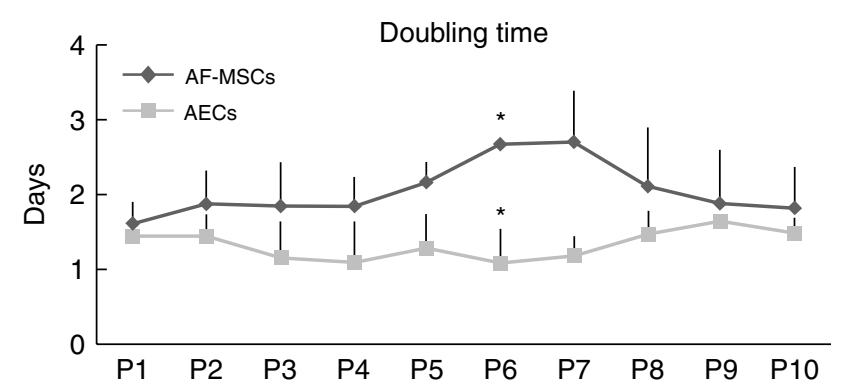

Figure 2 Doubling time over ten passages during cell culture for AECs and AF-MSCs. Statistically significant difference was observed in doubling time means between AECs and AF-MSCs $\left({ }^{*} P<0.05\right)$. 
Table 1 CFU assay.

\begin{tabular}{lrrr}
\hline $\left.\begin{array}{l}\text { Density } \\
(\text { cells/cm }\end{array}{ }^{2}\right)$ & Total cells & CFU & One CFU each \\
\hline AECs & & & \\
100 & 950 & $1.57 \pm 0.62^{\mathrm{a}, \mathrm{A}}$ & 605.10 \\
250 & 2375 & $21.63 \pm 3.15^{\mathrm{b}, \mathrm{B}}$ & 109.80 \\
500 & 4750 & $48 \pm 1.43^{\mathrm{c}, \mathrm{B}}$ & 98.96 \\
1000 & 9500 & $56.01 \pm 2.78^{\mathrm{c}, \mathrm{A}}$ & 169.61 \\
AF-MSCs & & & \\
100 & 950 & $1.07 \pm 0^{\mathrm{a}, \mathrm{A}}$ & 887.85 \\
250 & 2375 & $7.53 \pm 2.98^{\mathrm{a}, \mathrm{A}}$ & 315.41 \\
500 & 4750 & $26.95 \pm 4.72^{\mathrm{b}, \mathrm{A}}$ & 176.25 \\
1000 & 9500 & $40.53 \pm 3.99^{\mathrm{d}, \mathrm{B}}$ & 234.39 \\
\hline
\end{tabular}

Different small letters superscripts $(a, b$, and c) indicate statistically different comparisons $(P<0.05)$ between cell densities in each group (AECs or AF-MSCs). Different capital letter superscripts (A, B, and C) indicate statistically different comparisons $(P<0.05)$ between the same cell density among groups (AECs and AF-MSCs).

$P P A R G$, which is crucial for the preadipocyte commitment (Totonoz et al. 1994), and FABP4 and LEP that are regarded as intermediate and late markers of adipocyte differentiation were detected. AF-MSCs only expressed $F A B P 4$ and $L E P$ that are associated with the intermediate and late phases in developing adipocytes (Bernlohr et al. 1985), which may be led to a distinct developmental program characteristic of stem cells (Zuk et al. 2002). The potential of bovine MSCs to undergo chondrogenesis has been assessed by staining the cells with Alcian blue and confirmed using markers commonly associated with the chondrocyte phenotype: the early marker SOX9, collagen type 2 and ACAN, the most essential cartilage proteoglycan, and key markers of chondrocyte differentiation (Han \& Lefebvre 2008). In AECs and AF-MSCs, the expression of SOX9, which has been reported to regulate the rate of chondrocyte differentiation by controlling the expression of a series of chondrocyte-specific genes including $A C A N$ and COL2A1 (Tchetina et al. 2003), was detected. However, AECs and AF-MSCs showed a different pattern of expression in response to the activation of SOX9: ACAN expression was demonstrated in both cell lines, whereas a basal level of COL2A1 was only detected in AF-MSCs. The lack of expression of COL2A1 might be led to the culture conditions employed in this study as chondrogenic differentiation of MSCs in monolayer culture appears to be dose dependent and time dependent in relation to the bioactive factors used (Bosnakovski et al. 2004, 2005).

Bovine AF-MSCs represent a heterogeneous population originating from the three germ layers, whose cells share an epithelial origin and are derived from either the developing embryo or the inner surface of the amniotic membrane (Pappa \& Anagnou 2009). This was evident during the primary culture (at P0), when fibroblastic-like or flatter and circular cells were recognized. By the first passage, however, a selection of spindle-shaped cells occurred, according to what has been previously observed in equine species by our group (Lovati et al.
2011) or other researchers (lacono et al. 2012a). Amniotic epithelial cells displayed the typical polygonal morphology reported for human (Miki et al. 2005, 2007a) and equine species (Lange-Consiglio et al. 2012).

As shown by proliferation assays, cells from the epithelial portion of amnion had high and comparable proliferative capacity until passage 6 (Soncini et al. 2007, Miki et al. 2010). At that time, robust proliferation was still observed; however, AF-MSCs showed a higher doubling time $(2.69 \pm 0.32)$ compared with AECs (1.08 \pm 0.46$)$. When AF-MSCs and AECs were seeded at different densities, they were able to form clones with frequency that, in both cases, increased with the cellseeding density, suggesting that paracrine signaling between amnion- and AF-derived cells at P0 occurs (Sarugaser et al. 2005).

As suggested earlier, MSCs are the best-represented subpopulation within AF-SCs. To characterize this population, we evaluated the specific mesenchymal and pluripotent marker expression (Roubelakis et al. 2007, Soncini et al. 2007). Our data confirm this observation

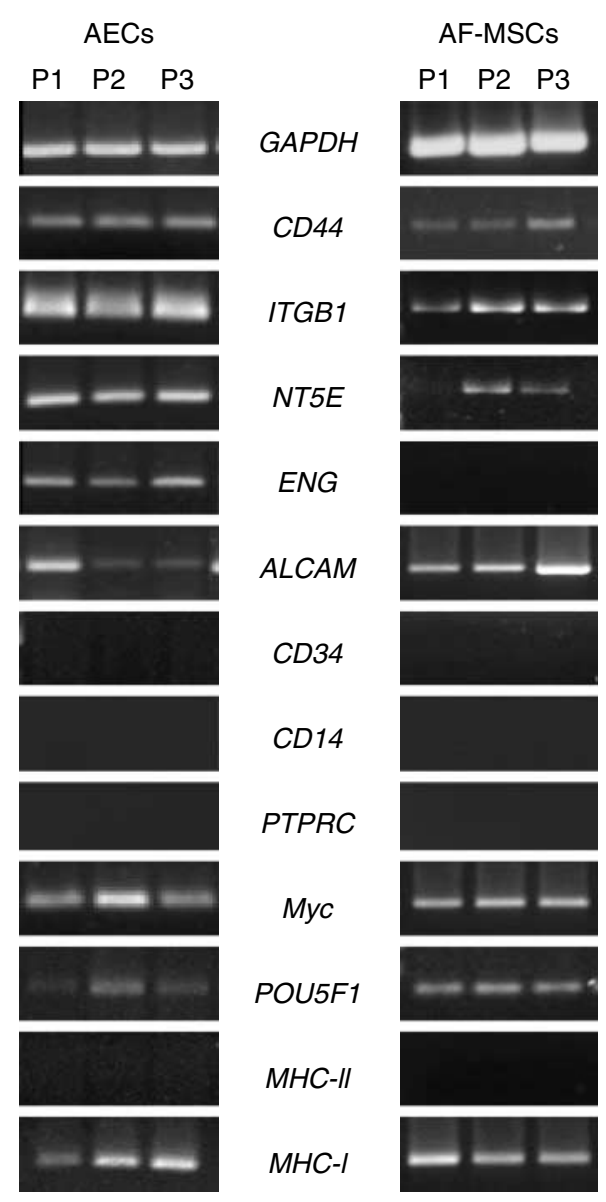

Figure 3 RT-PCR analysis of mesenchymal (ITGB1, CD44, ALCAM, NT5E, and ENG), pluripotent (POU5F1 and MYC), and hematopoietic (CD34, CD14, and PTPRC) specific gene expression on AECs and AF-MSCs from P1 to P3. MHC-Il was not detected. GAPDH has been employed as reference gene. 

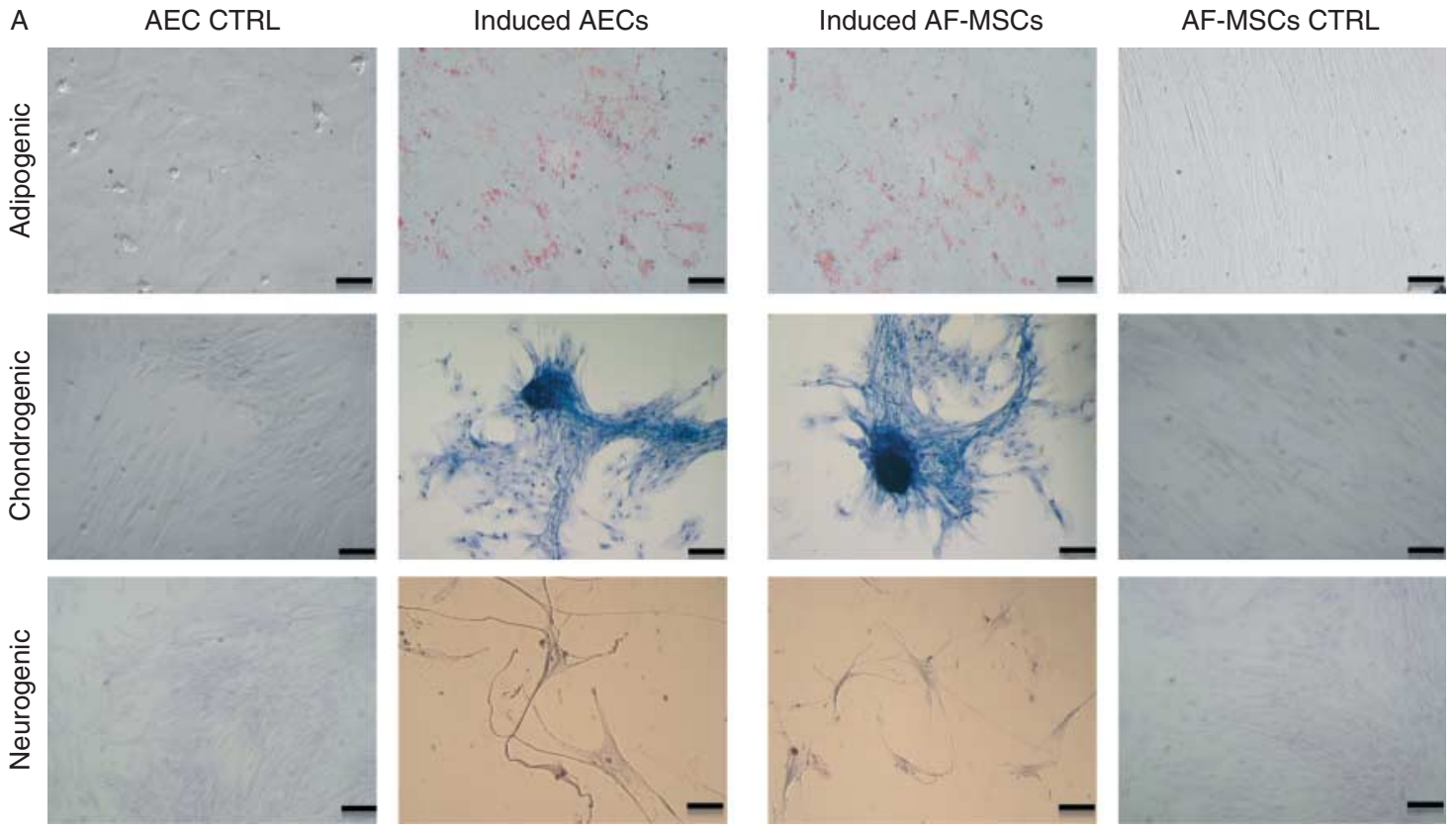

B

Adipogenic

Chondrogenic
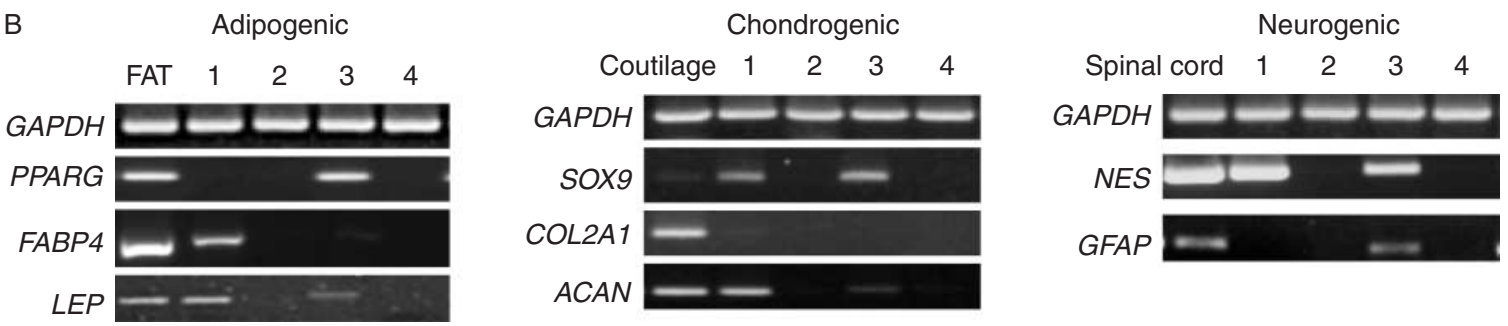

Figure 4 Multipotent differentiation potential of AECs and AF-MSCs. (A) Immunostaining on induced AECs and AF-MSCs and their controls (AECs CTRL and AF-MSCs CTRL). Oil Red O, Alcian blue, and Nissle staining to assess adipogenic, chondrogenic, and neurogenic differentiation respectively. Magnification, $20 \times$; scale bars, $20 \mu \mathrm{m}$. (B) RT-PCR analysis for PPARG, FABP4, and LEP for adipogenesis; SOX9, COL2A1, and ACAN for chondrogenesis; NES and GFAP for neurogenesis. Gene expression for the positive control (fat, cartilage, and spinal cord), induced cells (1 and 3 for AF-MSCs and AECs respectively), and their controls (2 and 4 for AF-MSCs and AECs respectively).

showing that mRNAs for CD44, ITGB1, and ALCAM can be detected in AF-MSCs as well as MHC-I, whereas these cells lack of $M H C-I I$ and the hematopoietic markers CD34, CD14, and PTPRC (Kim et al. 2007). NT5E was only observed by passage 2 and $E N G$ was not expressed at all. More importantly, cultured AF-MSCs expressed pluripotency markers such as the Octamer binding protein 3/4 (OCT3/4) and MYC (Pan et al. 2002, Tsai et al. 2004, Bossolasco et al. 2006, De Coppi et al. 2007, Roubelakis et al. 2007, 2011, Perin et al. 2010), which are known to maintain stem cell pluripotency and selfrenewal (Varlakhanova et al. 2010). Similarly, AECs were positive for CD44, ITGB1, NT5E, ENG, ALCAM, and $M H C-I$ and negative for CD34, CD14, PTPRC, and MHC-Il expression (Miki et al. 2007 b, 2010, Soncini et al. 2007, Marongiu et al. 2010, Manuelpillai et al. 2011). Further investigation demonstrated that AECs also express embryonic stem cell markers such as POU5F1 and MYC.

Our findings suggest, for the first time, that bovine amnion and AF represent alternative sources of progenitor cells to employ in cell-based therapies, in a similar manner to several other species (Chen et al. 2011, Lovati et al. 2011, lacono et al. 2012a, 2012b, Lange-Consiglio et al. 2012). Further studies, including pre-clinical and a deeper evaluation of immunological properties, are needed for the in vivo applications in order to better understand their role in cellular therapy.

In conclusion, the present data contribute to reinforce the emerging importance of the amniotic and extraembryonic tissues, making the cells derived from these tissues ideal tools in the veterinary regenerative medicine.

\section{Materials and Methods}

\section{Materials}

Chemicals were obtained from Sigma Chemical and tissue culture plastic dishes from Euroclone (Milan, Italy) unless otherwise specified. 


\section{Amnion and AF collection}

Samples were transported to the laboratory at $4{ }^{\circ} \mathrm{C}$ and processed within $8 \mathrm{~h}$. Two AFs were collected into sterile syringes during the full-term delivery of different cattle as previously reported (Lovati et al. 2011). When it was possible, the AF was aspirated into a sterile syringe directly from the vulva protruded amniotic sac before its spontaneous rupture. Allanto-amniotic membranes were obtained at term of normal pregnancies and after vaginal delivery from three cattle. Portions of allanto-amnion were kept at $4{ }^{\circ} \mathrm{C}$ in PBS (EuroClone) with $100 \mathrm{U} / \mathrm{ml}$ penicillin-100 mg/ml streptomycin and amphotericin B and were processed within $12 \mathrm{~h}$. The amniotic membrane was stripped from the overlying allantois and cut into small pieces (about $9 \mathrm{~cm}^{2}$ each) before enzymatic digestion.

\section{Isolation of amniotic epithelial cells}

Isolation of amniotic epithelial cells was performed as previously reported (Lange-Consiglio et al. 2012) in horse. Briefly, amnion fragments (about $12 \mathrm{~g}$ for an extension of $630 \mathrm{~cm}^{2}$ ) were incubated for 9 min at $37^{\circ} \mathrm{C}$ in PBS containing $2.4 \mathrm{U} / \mathrm{ml}$ dispase (Becton Dickinson, Milan, Italy). After a resting period (5-10 $\mathrm{min}$ ) at room temperature in high-glucose DMEM (HG-DMEM; EuroClone) supplemented with 10\% heatinactivated fetal bovine serum (FBS) and $2 \mathrm{mM}$ L-glutamine (Sigma), the fragments were digested twice with $0.05 \%(\mathrm{w} / \mathrm{v})$ trypsin/EDTA for $\sim 45 \mathrm{~min}$ at $37^{\circ} \mathrm{C}$ each time. The amnion fragments were then removed, and mobilized cells were passed through a $100 \mathrm{~mm}$ cell strainer before being collected by centrifugation at $200 \mathrm{~g}$ for $10 \mathrm{~min}$.

\section{Isolation of MSCs from AF}

Isolation of MSCs from AF was performed following the procedures previously described (Lovati et al. 2011), consisting of centrifuging the samples at $400 \mathrm{~g}$ for $10 \mathrm{~min}$, removing the supernatant and collecting the pellet formed at the bottom of the tube. Before seeding the cells, the pellet was washed three times in PBS.

\section{Cell culture}

Cultures were established in HG-DMEM supplemented with $10 \%$ FBS, $10 \mathrm{ng} / \mathrm{ml}$ epidermal growth factor, $1 \%$ penicillin (100 Ul/ml)-streptomycin $(100 \mathrm{mg} / \mathrm{ml}), 0.25 \mathrm{mg} / \mathrm{ml}$ amphotericin B, and $2 \mathrm{mM}$ L-glutamine. The number of viable cells was counted by the trypan blue dye exclusion method, using a Burker chamber. For maintenance of cultures, cells were plated at up to $1 \times 10^{5}$ cells $/ \mathrm{cm}^{2}$ and incubated at $38.5^{\circ} \mathrm{C}$ in a humidified atmosphere (90\%) with $5 \% \mathrm{CO}_{2}$. To remove nonadherent cells, the medium was replaced for the first time after $72 \mathrm{~h}$ and then changed either twice per week thereafter or according to the experiment requirements. Adherent cells were detached with $0.05 \%$ trypsin-EDTA (EuroClone) just before reaching confluence $(80 \%)$ and then reseeded for culture maintenance. Passage 3 was the last time point included for characterization and differentiation studies.

\section{Proliferation assays}

Proliferation of AECs and AF-MSCs has been determined as previously reported (Corradetti et al. 2011, Lange-Consiglio et al. 2012). Doubling time for passages 1-10 has been assessed plating $9 \times 10^{3}$ cells into six-well tissue culture plates. Every 4 days, cells were trypsinized, counted, and replated at the same density. Mean doubling time was calculated from days 0 to 4 . The mean of population doublings (PD) was obtained for each passage according to the formulae $C D=\log$ $(\mathrm{Nc} / \mathrm{No}) / \log _{2}$ and $\mathrm{PD}=\mathrm{CT} / \mathrm{CD}$, where $\mathrm{CD}$ represents cell doubling, Nc represents the number of cells at confluence, No represents seeded cells, and CT represents the culture time. Data representative of three independent experiments were reported.

\section{CFU assay}

CFU assays were performed at PO on freshly isolated cells at different densities (100, 250, 500, and 1000 cells/cm $\left.{ }^{2}\right)$. Cells were plated in six-well plates and cultured in $5 \% \mathrm{CO}_{2}$ and $90 \%$ humidity at $38.5^{\circ} \mathrm{C}$ for 2 weeks in HG-DMEM-supplemented medium. Then, colonies were fixed with $4 \%$ formalin and stained with $1 \%$ methylene blue (Serva, Heidelberg, Germany) in $10 \mathrm{mM}$ borate buffer, pH 8.8 (Fluka BioChemika, Buchs, Switzerland) at room temperature, and washed twice. Colonies formed by 16-20 nucleated cells were counted under a BX71 microscope (Olympus).

\section{RNA extraction and RT-PCR analysis}

Expression of specific MSC (CD44, ITGB1, NT5E, ENG, and ALCAM), pluripotent (MYC and POU5F1), and hematopoietic (CD34, CD14, and PTPRC) markers was investigated by RT-PCR analysis on undifferentiated cells. To evaluate whether cells could be well tolerated by the host once transplanted, expression of the $M H C-I$ and $M H C-I /$ was assessed. Total RNA was extracted at P1 and P3 from bovine AECs and AF-MSCs using TRIzol reagent (Invitrogen), followed by DNase treatment according to the manufacturer's specifications. RNA concentration and purity were measured using a NanoDrop ND1000 spectrophotometer (NanoDrop Technologies, Wilmington, DE, USA). cDNA was synthesized from $500 \mathrm{ng}$ total RNA, using the iScript retrotranscription kit (Bio-Rad Laboratories). Conventional PCR was performed in a $25 \mathrm{ml}$ final volume with DreamTaq DNA Polymerase (Fermentas, St Leon Rot, Germany) under the following conditions: initial denaturation at $95{ }^{\circ} \mathrm{C}$ for $2 \mathrm{~min}, 32$ cycles at $95{ }^{\circ} \mathrm{C}$ for $30 \mathrm{~s}$ (denaturation), $55-63{ }^{\circ} \mathrm{C}$ for $30 \mathrm{~s}$ (annealing), $72{ }^{\circ} \mathrm{C}$ for $30 \mathrm{~s}$ (elongation), and final elongation at $72{ }^{\circ} \mathrm{C}$ for $10 \mathrm{~min}$.

For differentiation experiments, total RNA was extracted from undifferentiated (control cells) and from induced amnionor AF-derived cells, and RT-PCR analysis was performed as described earlier. Bovine adult tissues (fat, cartilage, and spinal cord) were employed as positive controls for assessing the expression of PPARG, FABP4 and LEP for adipogenesis, the Sry-related high-mobility group box transcription factor (SOX9), collagen type $2 \alpha 1$ (COL2A1) and ACAN for chondrogenesis, and GFAP and NES for neurogenesis. Bovine-specific 
Table 2 Oligonucleotide sequences used for RT-PCR analysis.

\begin{tabular}{|c|c|c|c|c|}
\hline Markers & Forward $\left(5^{\prime} \rightarrow 3^{\prime}\right)$ & Reverse $\left(5^{\prime} \rightarrow 3^{\prime}\right)$ & $\begin{array}{c}\text { Annealing } \\
\text { temperature }\left({ }^{\circ} \mathrm{C}\right)\end{array}$ & $\begin{array}{c}\text { Product } \\
\text { length }(b p)\end{array}$ \\
\hline $\begin{array}{l}\text { POU class } 5 \text { homeobox } 1 \\
\text { (POU5F1) }\end{array}$ & CACACTAGGATATACCCAGGC & GGAGATATGCAAGGCAGAGA & 60 & 177 \\
\hline MYC & GCGCCGCATTCGCGAAACTT & TGAGGGGCATCGCTGCAAGC & 58 & 214 \\
\hline $\begin{array}{l}\text { Major histocompatibility } \\
\text { complex I (MHC-I) }\end{array}$ & GATCTCAСТGACСТGGCA & CTGAGGAGGTTCССАTСTC & 60 & 199 \\
\hline MHC-II & ССТСGСТTGССТGАATTTGC & ACAGGTGCCGACTGATGC & 53 & 299 \\
\hline ALCAM & GTATTTATTGCCTTCAGGTCCT & TCTACCAGGGAGCATTTATAGTC & 59 & 755 \\
\hline Ecto-5'-nucleotidase (NT5E) & AAGGTTCCTGTGGTCCAGGCCT & TGCATTCTCGAAAGCGGCAGGA & 68 & 260 \\
\hline $\begin{array}{l}\text { Glyceraldehyde-3-phosphate } \\
\text { dehydrogenase }(G A P D H)\end{array}$ & ATGAGATCAAGAAGGTGGTG & CCAAATTCATTGTCGTACCAG & 60 & 190 \\
\hline Integrin $\beta 1$ (ITGB1) & GTTGGTTCTGCAGTTACGATCAG & AACCAAACCCAATTCGGAAGTC & 52 & 203 \\
\hline CD44 antigen (CD44) & AACAGTAGGAGAAGGTGTGG & TCATGAACTGGTCTTGGGTC & 61 & 166 \\
\hline Endoglin (ENG) & ACAAGTCTTGCAGAAACAGTC & GATGTCTGGAGAGTCAGCTC & 61 & 182 \\
\hline PTPRC molecule (CD45) & СTTCTGGCATTCGGCTTTGC & AATGGAGGCTCACACGAAGG & 58 & 350 \\
\hline CD14 molecule (CD14) & TCCGAAGCCTGACTGGTCTA & TGTCGGCTCCСTTGAGAAAC & 56 & 104 \\
\hline CD34 & ССТGAAGCTAAATGAGACCT & AACTTTCTGTCCTGTTGGTC & 58 & 173 \\
\hline Leptin $(L E P)$ & САATGACATCTCACACACGCAG & CGGCCAGCAGGTGGAGAAG & 55 & 212 \\
\hline $\begin{array}{l}\text { Adipocyte fatty acid-binding } \\
\text { protein (FABP4) }\end{array}$ & CTGGCATGGCCAAACCCA & GTACTTGTACCAGAGCACC & 55 & 182 \\
\hline $\begin{array}{l}\text { Peroxisome proliferator-activated } \\
\text { receptor (PPARG) }\end{array}$ & CGCACTGGAATTAGATGACAGC & CACAATCTGTCTGAGGTCTGTC & 55 & 199 \\
\hline $\begin{array}{l}\text { Sex-determining region Y-box } 9 \\
\quad(S O X 9)\end{array}$ & CATGAAGATGACCGACGAG & CGTCTTCTCCGTGTCGGA & 55 & 118 \\
\hline Collagen type 1 , alpha I (COL1A1) & CGCGGATTTGTTGCTGCTTGC & AGGTCCCATCAGCCCCATTGGT & 55 & 269 \\
\hline Aggrecan $(A C A N)$ & CGCTGTCTCGCCAAGTGTATGG & CGGTTCAGGGATGCTGACACTC & 60 & 175 \\
\hline $\begin{array}{l}\text { Glial fibrillary acidic protein } \\
(G F A P)\end{array}$ & GGCACCTTGAGGCAGAAGCTC & СТССТGGAGСТСССGСАССТ & 60 & 195 \\
\hline Nestin (NES) & ACCACTGAGCAGTTCCAGCTGG & TTGCAGGTGTCTGCAGCCGT & 55 & 187 \\
\hline
\end{tabular}

oligonucleotide primers were designed using open source PerlPrimer Software v. 1.1.17 (Marshall 2004), based on available NCBI Bos taurus sequences or on Mammal multialigned sequences. Primers were designed across an exon-exon junction in order to avoid DNA amplification. Primers were used at $300 \mathrm{nM}$ final concentrations. Their sequences and the conditions used to amplify each gene are shown in Table 2. GAPDH was employed as a reference gene.

\section{Differentiation assays}

Cells at P3 were seeded at a density of $3 \times 10^{3} / \mathrm{cm}^{2}$ for all differentiation studies. Adipogenic, chondrogenic, and neurogenic differentiation were assessed as previously reported (Corradetti et al. 2011, Lange-Consiglio et al. 2012). Noninduced control cells were cultured for the same time in standard control medium (HG-DMEM supplemented with $10 \% \mathrm{FBS}, 100 \mathrm{U} / \mathrm{ml}$ penicillin, $100 \mathrm{mg} / \mathrm{ml}$ streptomycin, $0.25 \mathrm{mg} / \mathrm{ml}$ amphotericin B, and $2 \mathrm{mM}$ L-glutamine). Adipogenesis using conventional Oil red $\mathrm{O}$ staining $(0.1 \%$ in $60 \%$ isopropanol) demonstrated lipid droplets; chondrogenesis was demonstrated by Alcian blue staining $(\mathrm{pH} 2.5)$, and neurogenic by conventional Nissl staining ( $0.1 \%$ cresyl violet solution), which showed increasing ribosomes.

\section{Statistical analysis}

Statistical analysis was performed using GraphPad Instat 3.00 for Windows (GraphPad Software, La Jolla, CA, USA). Three replicates for each experiment (doubling times and CFU) were performed and the results are reported as mean \pm s.D. One-way ANOVA for multiple comparisons by Student-Newman-Keuls multiple comparison tests was used. CFU comparison among different cell plating densities inside each group (AECs or AF-MSCs) and between groups (AECs and AF-MSCs) of the same cell density were analyzed. $P<0.05$ was considered as significant.

\section{Declaration of interest}

The authors declare that there is no conflict of interest that could be perceived as prejudicing the impartiality of the research reported.

\section{Funding}

This research did not receive any specific grant from any funding agency in the public, commercial or not-for-profit sector.

\section{References}

Arcelli R, Tibaldini P, Angeli G \& Bellezza E 2009 Equine amniotic membrane transplantation in some ocular surface diseases in the dog and cat: a preliminary study. Veterinary Research Communications 33 (Suppl 1) 169-171. (doi:10.1007/s11259-009-9284-6)

Arnhold SJ, Goletz I, Klein H, Stumpf G, Beluche LA, Rohde C, Addicks K \& Litzke LF 2007 Isolation and characterization of bone marrow-derived equine mesenchymal stem cells. American Journal of Veterinary Research 68 1095-1105. (doi:10.2460/ajvr.68.10.1095) 
Avila M, Espana M, Moreno C \& Pena C 2001 Reconstruction of ocular surface with heterologous limbal epithelium and amniotic membrane in a rabbit model. Cornea 20 414-420. (doi:10.1097/00003226200105000-00016)

Bartholomew S, Owens SD, Ferraro GL, Carrade DD, Lara DJ, Librach FA, Borjesson DL \& Galuppo LD 2009 Collection of equine cord blood and placental tissues in 40 thoroughbred mares. Equine Veterinary Journal 41 724-728. (doi:10.2746/042516409X429446)

Bernlohr DA, Doering TL, Kelly TJ \& Lane MD 1985 Tissue specific expression of p422 protein, a putative lipid carrier in mouse adipocytes. Biochemical and Biophysical Research Communications 132 850-855. (doi:10.1016/0006-291X(85)91209-4)

Bosnakovski D, Mizuno M, Kim G, Ishiguro T, Okumura M, Iwanaga T, Kadosawa T \& Fujinaga T 2004 Chondrogenic differentiation of bovine bone marrow mesenchymal stem cells in pellet cultural system. Experimental Hematology 32 502-509. (doi:10.1016/j.exphem.2004. 02.009)

Bosnakovski D, Mizuno M, Kim G, Takagi S, Okumura M \& Fujinaga T 2005 Isolation and multilineage differentiation of bovine bone marrow mesenchymal stem cells. Cell and Tissue Research 319 243-253. (doi:10.1007/s00441-004-1012-5)

Bosnakovski D, Mizuno M, Kim G, Takagi S, Okumura M \& Fujinaga T 2006 Chondrogenic differentiation of bovine bone marrow mesenchymal stem cells (MSCs) in different hydrogels: influence of collagen type II extracellular matrix on MSC chondrogenesis. Biotechnology and Bioengineering 93 1152-1163. (doi:10.1002/bit.20828)

Bossolasco P, Montemurro T, Cova L, Zangrossi S, Calzarossa C, Buiatiotis S, Soligo D, Bosari S, Silani V, Deliliers GL et al. 2006 Molecular and phenotypic characterization of human amniotic fluid cells and their differentiation potential. Cell Research 16 329-336. (doi:10.1038/sj.cr.7310043)

Carlin R, Davis D, Weiss M, Schultz B \& Troyer D 2006 Expression of early transcription factors Oct-4, Sox-2 and Nanog by porcine umbilical cord (PUC) matrix cells. Reproductive Biology and Endocrinology 48. (doi:10.1186/1477-7827-4-8)

Chen J, Lu Z, Cheng D, Peng S \& Wang H 2011 Isolation and characterization of porcine amniotic fluid-derived multipotent stem cells. PLoS ONE 6 e19964. (doi:10.1371/journal.pone.0019964)

Corradetti B, Lange-Consiglio A, Barucca M, Cremonesi F \& Bizzaro D 2011 Size-sieved subpopulations of mesenchymal stem cells from intervascular and perivascular equine umbilical cord matrix. Cell Proliferation 44 330-342. (doi:10.1111/j.1365-2184.2011.00759.x)

Cremonesi F, Violini S, Lange Consiglio A, Ramelli P, Ranzenigo G \& Mariani P 2008 Isolation, in vitro culture and characterization of foal umbilical cord stem cells at birth. Veterinary Research Communications 32 (Suppl 1) S139-S142. (doi:10.1007/s11259-008-9116-0)

Da Sacco S, De Filippo RE \& Perin L 2007 Amniotic fluid as a source of pluripotent and multipotent stem cells for organ regeneration. Current Opinion in Organ Transplantation 183 1193-1200. (doi:10.1097/MOT. Ob013e3283424f6e)

De Coppi P, Bartsch G Jr, Siddiqui MM, Xu T, Santos CC, Perin L, Mostoslavsky G, Serre AC, Snyder EY, Yoo JJ et al. 2010 Isolation of amniotic stem cell lines with potential for therapy. Nature Biotechnology 25 100-106. (doi:10.1038/nbt1274)

Delo DM, De Coppi P, Bartsch G Jr \& Atala A 2006 Amniotic fluid and placental stem cells. Methods in Enzymology 419 426-438. (doi:10.1016/S0076-6879(06)19017-5)

Dev K, Giri S, Kumar A, Yadav A, Singh B \& Gautam S 2011 Derivation, characterization and differentiation of buffalo (Bubalus bubalis) amniotic fluid derived stem cells. Reproduction in Domestic Animals 47 704-711. (doi:10.1111/j.1439-0531.2011.01947.x)

Dua HS, Gomes JA, King AJ \& Maharajan VS 2004 The amniotic membrane in ophthalmology. Survey of Ophthalmology 49 51-77. (doi:10.1016/ j.survophthal.2003.10.004)

Filioli Uranio M, Valentini L, Lange-Consiglio A, Caira M, Guaricci AC, L'Abbate A, Catacchio CR, Ventura M, Cremonesi F \& Dell'Aquila ME 2011 Isolation, proliferation, cytogenetic, and molecular characterization and in vitro differentiation potency of canine stem cells from foetal adnexa: a comparative study of amniotic fluid, amnion, and umbilical cord matrix. Molecular Reproduction and Development 78 361-373. (doi:10.1002/mrd.21311)
Fortier LA, Nixon AJ, Williams J \& Cable CS 1998 Isolation and chondrocytic differentiation of equine bone marrow-derived mesenchymal stem cells. American Journal of Veterinary Research 59 1182-1187.

Giovannini S, Brehm W, Mainil-Varlet P \& Nesic D 2008 Multilineage differentiation potential of equine blood-derived fibroblast-like cells. Differentiation 76 118-129. (doi:10.1111/j.1432-0436.2007.00207.x)

Gucciardo L, Lories R, Ochsenbein-Kolble N, Done E, Zwijsen A \& Deprest J 2009 Fetal mesenchymal stem cells: isolation, properties and potential use in perinatology and regenerative medicine. BJOG: an International Journal of Obstetrics and Gynaecology 116 166-172. (doi:10.1111/j.1471-0528.2008.02005.x)

Guest DJ 2008 Defining the expression of marker genes in equine mesenchymal stromal cells. Stem Cells and Cloning: Advances and Applications 1 1-9. (doi:10.2147/SCCAA.S3824)

Han Y \& Lefebvre V 2008 L-Sox5 and Sox6 drive expression of the aggrecan gene in cartilage by securing binding of Sox 9 to a far-upstream enhancer. Molecular and Cellular Biology 28 4999-5013. (doi:10.1128/MCB. 00695-08)

Hoynowski SM, Fry MM, Gardner BM, Leming MT, Tucker JR, Black L, Sand T \& Mitchell KE 2007 Characterization and differentiation of equine umbilical cord-derived matrix cells. Biochemical and Biophysical Research Communications 362 347-353. (doi:10.1016/j.bbrc.2007. 07.182)

lacono E, Brunori L, Pirrone A, Pagliaro PP, Ricci F, Tazzari PL \& Merlo B 2012a Isolation, characterization and differentiation of mesenchymal stem cells from amniotic fluid, umbilical cord blood and Wharton's jelly in the horse. Reproduction 143 455-468. (doi:10.1530/REP-100408)

Iacono E, Cunto M, Zambelli D, Ricci F, Tazzari PL \& Merlo B $2012 b$ Could fetal fluid and membranes be an alternative source for mesenchymal stem cells (MSCs) in the feline species? A preliminary study Veterinary Research Communications 36 107-118. (doi:10.1007/s11259-0129520-3)

In 't Anker PS, Scherjon SA, Kleijburg-van der Keur C, de GrootSwings GM, Claas FH, Fibbe WE \& Kanhai HH 2004 Isolation of mesenchymal stem cells of fetal or maternal origin from human placenta. Stem Cells 22 1338-1345. (doi:10.1634/stemcells.2004-0058)

Kern S, Eichler H, Stoeve J, Kluter H \& Bieback K 2006 Comparative analysis of mesenchymal stem cells from bone marrow, umbilical cord blood, or adipose tissue. Stem Cells 24 1294-1301. (doi:10.1634/ stemcells.2005-0342)

Kim J, Lee Y, Kim H, Hwang KJ, Kwon HC, Kim SK, Cho DJ, Kang SG \& You J 2007 Human amniotic fluid-derived stem cells have characteristics of multipotent stem cells. Cell Proliferation 40 75-90. (doi:10.1111/ j.1365-2184.2007.00414.x)

Koch TG, Heerkens T, Thomsen PD \& Betts DH 2007 Isolation of mesenchymal stem cells from equine umbilical cord blood. BMC Biotechnology 7 26. (doi:10.1186/1472-6750-7-26)

Koerner J, Nesic D, Romero JD, Brehm W, Mainil-Varlet P \& Grogan SP 2006 Equine peripheral blood-derived progenitors in comparison to bone marrow-derived mesenchymal stem cells. Stem Cells 24 1613-1619. (doi:10.1634/stemcells.2005-0264)

Kogler G, Sensken S, Airey JA, Trapp T, Muschen M, Feldhahn N, Liedtke S, Sorg RV, Fischer J, Rosenbaum C et al. 2004 A new human somatic stem cell from placental cord blood with intrinsic pluripotent differentiation potential. Journal of Experimental Medicine 200 123-135. (doi:10.1084/ jem.20040440)

Kubo M, Sonoda Y, Muramatsu R \& Usui M 2001 Immunogenicity of human amniotic membrane in experimental xenotransplantation. Investigative Ophthalmology \& Visual Science 42 1539-1546.

Lange-Consiglio A, Corradetti B, Bizzaro D, Magatti M, Ressel L, Tassan S, Parolini O \& Cremonesi F 2012 Characterization and potential applications of progenitor-like cells isolated from horse amniotic membrane. Journal of Tissue Engineering and Regenerative Medicine 6 622-635. (doi:10.1002/term.465)

Lovati AB, Corradetti B, Lange Consiglio A, Recordati C, Bonacina E, Bizzaro D \& Cremonesi F 2011 Comparison of equine bone marrow-, umbilical cord matrix and amniotic fluid-derived progenitor cells. Veterinary Research Communications 35 103-121. (doi:10.1007/ s11259-010-9457-3) 
Magatti M, De Munari S, Vertua E, Gibelli L, Wengler GS \& Parolini O 2008 Human amnion mesenchyme harbors cells with allogeneic T-cell suppression and stimulation capabilities. Stem Cells 26 182-192. (doi:10.1634/stemcells.2007-0491)

Manuelpillai U, Moodley Y, Borlongan CV \& Parolini O 2011 Amniotic membrane and amniotic cells: potential therapeutic tools to combat tissue inflammation and fibrosis? Placenta 32 (Suppl 4) S320-S325. (doi:10.1016/j.placenta.2011.04.010)

Marongiu F, Gramignoli R, Sun Q, Tahan V, Miki T, Dorko K, Ellis E \& Strom SC 2010 Isolation of amniotic mesenchymal stem cells. Current Protocols in Stem Cell Biology (chapter 1 unit 1E 5). (doi:10.1002/ 9780470151808.sc01e05s12)

Marshall OJ 2004 PerlPrimer: cross-platform, graphical primer design for standard, bisulphite and real-time PCR. Bioinformatics 20 2471-2472.

Miki T, Lehmann T, Cai H, Stolz DB \& Strom SC 2005 Stem cell characteristics of amniotic epithelial cells. Stem Cells 23 1549-1559. (doi:10.1634/stemcells.2004-0357)

Miki T, Marongiu F, Ellis E \& Strom SC 2007 a Isolation of amniotic epithelial stem cells. Current Protocols in Stem Cell Biology (chapter 1 unit 1E 3). (doi:10.1002/9780470151808)

Miki T, Mitamura K, Ross MA, Stolz DB \& Strom SC $2007 b$ Identification of stem cell marker-positive cells by immunofluorescence in term human amnion. Journal of Reproductive Immunology 75 91-96. (doi:10.1016/ j.jri.2007.03.017)

Miki T, Marongiu F, Dorko K, Ellis EC \& Strom SC 2010 Isolation of amniotic epithelial stem cells. Current Protocols in Stem Cell Biology (chapter 1 unit 1E 3). (doi:10.1002/9780470151808)

Mitchell KE, Weiss ML, Mitchell BM, Martin P, Davis D, Morales L, Helwig B, Beerenstrauch M, Abou-Easa K, Hildreth T et al. 2003 Matrix cells from Wharton's jelly form neurons and glia. Stem Cells 21 50-60. (doi:10.1634/stemcells.21-1-50)

Ollivier FJ, Kallberg ME, Plummer CE, Barrie KP, O'Reilly S, Taylor DP, Gelatt KN \& Brooks DE 2006 Amniotic membrane transplantation for corneal surface reconstruction after excision of corneolimbal squamous cell carcinomas in nine horses. Veterinary Ophthalmology 9 404-413. (doi:10.1111/j.1463-5224.2006.00480.x)

Pan GJ, Chang ZY, Scholer HR \& Pei D 2002 Stem cell pluripotency and transcription factor Oct4. Cell Research 12 321-329. (doi:10.1038/sj.cr. 7290134)

Pappa KI \& Anagnou NP 2009 Novel sources of fetal stem cells: where do they fit on the developmental continuum? Regenerative Medicine $\mathbf{4}$ 423-433. (doi:10.2217/rme.09.12)

Parolini O, Alviano F, Bagnara GP, Bilic G, Buhring HJ, Evangelista M, Hennerbichler S, Liu B, Magatti M, Mao N et al. 2008 Concise review: isolation and characterization of cells from human term placenta: outcome of the first international Workshop on Placenta Derived Stem Cells. Stem Cells 26 300-311. (doi:10.1634/stemcells.2007-0594)

Parolini O, Soncini M, Evangelista M \& Schmidt D 2009 Amniotic membrane and amniotic fluid-derived cells: potential tools for regenerative medicine? Regenerative Medicine 4 275-291. (doi:10.2217/ 17460751.4.2.275)

Passeri S, Nocchi F, Lamanna R, Lapi S, Miragliotta V, Giannessi E, Abramo F, Stornelli MR, Matarazzo M, Plenteda D et al. 2009 Isolation and expansion of equine umbilical cord-derived matrix cells (EUCMCs). Cell Biology International 33 100-105. (doi:10.1016/j.cellbi. 2008.10.012)

Perin L, Sedrakyan S, Giuliani S, Da Sacco S, Carraro G, Shiri L, Lemley KV, Rosol M, Wu S, Atala A et al. 2010 Protective effect of human amniotic fluid stem cells in an immunodeficient mouse model of acute tubular necrosis. PLoS ONE 5 e9357. (doi:10.1371/journal.pone.0009357)

Pittenger MF, Mackay AM, Beck SC, Jaiswal RK, Douglas R, Mosca JD, Moorman MA, Simonetti DW, Craig S \& Marshak DR 1999 Multilineage potential of adult human mesenchymal stem cells. Science $\mathbf{2 8 4}$ 143-147. (doi:10.1126/science.284.5411.143)

Plummer CE, Ollivier F, Kallberg M, Brooks D, Barrie K, Utter M \& Gelatt K 2009 The use of amniotic membrane transplantation for ocular surface reconstruction: a review and series of 58 equine clinical cases (2002-2008). Veterinary Ophthalmology 12 (Suppl 1) 17-24. (doi:10.1111/j.1463-5224.2009.00741.x)

Prusa AR \& Hengstschlager M 2002 Amniotic fluid cells and human stem cell research: a new connection. Medical Science Monitor 8 RA253-RA257.
Raoufi MF, Tajik P, Dehghan MM, Eini F \& Barin A 2011 Isolation and differentiation of mesenchymal stem cells from bovine umbilical cord blood. Reproduction in Domestic Animals 46 95-99. (doi:10.1111/ j.1439-0531.2010.01594.x)

Reed SA \& Johnson SE 2008 Equine umbilical cord blood contains a population of stem cells that express Oct4 and differentiate into mesodermal and endodermal cell types. Journal of Cellular Physiology 215 329-336. (doi:10.1002/jcp.21312)

Ringe J, Kaps C, Schmitt B, Buscher K, Bartel J, Smolian H, Schultz O, Burmester GR, Haupl T \& Sittinger M 2002 Porcine mesenchymal stem cells. Induction of distinct mesenchymal cell lineages. Cell and Tissue Research 307 321-327. (doi:10.1007/s00441-002-0525-z)

Roubelakis MG, Pappa KI, Bitsika V, Zagoura D, Vlahou A, Papadaki HA, Antsaklis A \& Anagnou NP 2007 Molecular and proteomic characterization of human mesenchymal stem cells derived from amniotic fluid: comparison to bone marrow mesenchymal stem cells. Stem Cells and Development 16 931-952. (doi:10.1089/scd.2007.0036)

Roubelakis MG, Bitsika V, Zagoura D, Trohatou O, Pappa KI, Makridakis M, Antsaklis A, Vlahou A \& Anagnou NP 2011 In vitro and in vivo properties of distinct populations of amniotic fluid mesenchymal progenitor cells. Journal of Cellular and Molecular Medicine $\mathbf{1 5}$ 1896-1913. (doi:10.1111/j.1582-4934.2010.01180.x)

Sankar V \& Muthusamy R 2003 Role of human amniotic epithelial cell transplantation in spinal cord injury repair research. Neuroscience $\mathbf{1 1 8}$ 11-17. (doi:10.1016/S0306-4522(02)00929-6)

Sarugaser R, Lickorish D, Baksh D, Hosseini MM \& Davies JE 2005 Human umbilical cord perivascular (HUCPV) cells: a source of mesenchymal progenitors. Stem Cells 23 220-229. (doi:10.1634/ stemcells.2004-0166)

Schuh EM, Friedman MS, Carrade DD, Li J, Heeke D, Oyserman SM, Galuppo LD, Lara DJ, Walker NJ, Ferraro GL et al. 2009 Identification of variables that optimize isolation and culture of multipotent mesenchymal stem cells from equine umbilical-cord blood. American Journal of Veterinary Research 70 1526-1535. (doi:10.2460/ajvr.70.12.1526)

Seo MS, Jeong YH, Park JR, Park SB, Rho KH, Kim HS, Yu KR, Lee SH, Jung JW, Lee YS et al. 2009 Isolation and characterization of canine umbilical cord blood-derived mesenchymal stem cells. Journal of Veterinary Science 10 181-187. (doi:10.4142/jvs.2009.10.3.181)

Sessarego N, Parodi A, Podesta M, Benvenuto F, Mogni M, Raviolo V, Lituania M, Kunkl A, Ferlazzo G, Bricarelli FD et al. 2008 Multipotent mesenchymal stromal cells from amniotic fluid: solid perspectives for clinical application. Haematologia 93 339-346. (doi:10.3324/haematol.11869)

Smith RK, Korda M, Blunn GW \& Goodship AE 2003 Isolation and implantation of autologous equine mesenchymal stem cells from bone marrow into the superficial digital flexor tendon as a potential novel treatment. Equine Veterinary Journal 35 99-102. (doi:10.2746/ 042516403775467388)

Solomon A, Wajngarten M, Alviano F, Anteby I, Elchalal U, Pe'er J \& Levi-Schaffer F 2005 Suppression of inflammatory and fibrotic responses in allergic inflammation by the amniotic membrane stromal matrix. Clinical and Experimental Allergy 35 941-948. (doi:10.1111/ j.1365-2222.2005.02285.x)

Soncini M, Vertua E, Gibelli L, Zorzi F, Denegri M, Albertini A, Wengler GS \& Parolini O 2007 Isolation and characterization of mesenchymal cells from human fetal membranes. Journal of Tissue Engineering and Regenerative Medicine 1 296-305. (doi:10.1002/term.40)

Tchetina E, Mwale F \& Poole AR 2003 Distinct phases of coordinated early and late gene expression in growth plate chondrocytes in relationship to cell proliferation, matrix assembly, remodeling, and cell differentiation. Journal of Bone and Mineral Research 18 844-851. (doi:10.1359/jbmr. 2003.18.5.844)

Totonoz P, Hu E, Graves RA, Budvari AI \& Speigelman BM 1994 mPPAR $\gamma 2$ : tissue-specific regulator of an adipocyte enhancer. Genes and Development 8 1224-1234. (doi:10.1101/gad.8.10.1224)

Tsai MS, Lee JL, Chang YJ \& Hwang SM 2004 Isolation of human multipotent mesenchymal stem cells from second-trimester amniotic fluid using a novel two-stage culture protocol. Human Reproduction 19 1450-1456. (doi:10.1093/humrep/deh279)

Varlakhanova NV, Cotterman RF, deVries WN, Morgan J, Donahue LR, Murray S, Knowles BB \& Knoepfler PS 2010 Myc maintains embryonic stem cell pluripotency and self-renewal. Differentiation 80 9-19. (doi:10.1016/j.diff.2010.05.001) 
Vidal MA, Kilroy GE, Johnson JR, Lopez MJ, Moore RM \& Gimble JM 2006 Cell growth characteristics and differentiation frequency of adherent equine bone marrow-derived mesenchymal stromal cells: adipogenic and osteogenic capacity. Veterinary Surgery 35 601-610. (doi:10.1111/ j.1532-950X.2006.00197.x)

Vidal MA, Robinson SO, Lopez MJ, Paulsen DB, Borkhsenious O, Johnson JR, Moore RM \& Gimble JM 2008 Comparison of chondrogenic potential in equine mesenchymal stromal cells derived from adipose tissue and bone marrow. Veterinary Surgery 37 713-724. (doi:10.1111/ j.1532-950X.2008.00462.x)

Wang M, Yoshida H, Kawashima H, Ishizaki M, Takahashi TA \& Hori J 2006 Immunogenicity and antigenicity of allogenic amniotic epithelial transplants grafted to the cornea, conjunctiva, and anterior chamber. Investigative Ophthalmology \& Visual Science 47 1522-1532. (doi:10.1167/iovs.05-0787)

You Q, Tong X, Guan Y, Zhang D, Huang M, Zhang Y \& Zheng J 2009 The biological characteristics of human third trimester amniotic fluid stem cells. Journal of International Medical Research 37 105-112.
Yuge I, Takumi Y, Koyabu K, Hashimoto S, Takashima S, Fukuyama T, Nikaido T \& Usami S 2004 Transplanted human amniotic epithelial cells express connexin 26 and $\mathrm{Na}-\mathrm{K}$-adenosine triphosphatase in the inner ear. Transplantation 77 1452-1454. (doi:10.1097/00007890-20040515000023)

Zheng YM, Zhao XE \& An ZX 2010 Neurogenic differentiation of EGFP gene transfected amniotic fluid-derived stem cells from pigs at intermediate and late gestational ages. Reproduction in Domestic Animals 45 e78-e82. (doi:10.1111/j.1439-0531.2009.01568.x)

Zuk PA, Zhu M, Ashjian P, De Ugarte DA, Huang JI, Mizuno H, Alfonso ZC, Fraser JK, Benhaim P \& Hedrick MH 2002 Human adipose tissue is a source of multipotent stem cells. Molecular Biology of the Cell $\mathbf{1 3}$ 4279-4295. (doi:10.1091/mbc.E02-02-0105)

Received 2 November 2012

First decision 3 December 2012

Accepted 12 February 2013 